\title{
ORAL AND DENTAL MANAGEMENT IN CHILDREN WITH TETRALOGY OF FALLOT : A LITERATURE REVIEW
}

Welly Anggarani*, Sandy Christiono*, Prima Agusmawanti*

^ Departemen IImu Kedokteran Gigi Anak Fakultas Kedokteran Gigi Universitas Islam Sultan Agung

Correspondence : welly@unissula.ac.id

Keywords:

oral and dental management, congenital heart disease, Tetralogy Of Fallot

\section{ABSTRACT}

Background: Congenital heart disease is a condition of heart anomaly and or disfunction of heart since birth. The most common congenital heart disease is Tetralogy Of Fallot (TOF). The disorder has four features, a ventricular septal defect, aortic overriding, stenosis pulmonary, and hypertrophy right ventricular. Method: This review aimed to talk about oral manifestations and discuss options of several oral and dental management in children with TOF.

Result: Oral and dental treatment of pediatric patient with cardiovascular disease is important to be carried out with the risk of bacterial endocarditis.

Conclusion: Oral and dental management in a child with congenital heart disease is very important. Main point of dental management are dental health education, preventive dental treatment and control periodic after dental treatment.

\section{PENDAHULUAN}

Penyakit jantung kongenital merupakan kelainan struktural atau susunan jantung dan pembuluh darah besar intratoraks, yang berpotensi atau secara nyata memberikan pengaruh fungsional yang signifikan, mungkin sudah terdapat sejak lahir ${ }^{1}$. Di Indonesia, angka kejadian 8 tiap 1000 kelahiran hidup. Secara garis besar penyakit jantung kongenital dibagi atas dua kelompok, yaitu sianotik dan asianotik. Pada penyakit jantung kongenital sianotik terjadi sianosis sentral oleh karena aliran darah paru berkurang akibat obstruksi aliran keluar ventrikel kanan sehingga terjadi pirau kanan ke kiri².

Tetralogy of Fallot (ToF) merupakan penyakit jantung kongenital sianotik yang paling banyak ditemukan, yakni lebih kurang $10 \%$ dari seluruh kejadian penyakit jantung congenital pada anakanak. Tetralogy of fallot memiliki empat kelainan khas, yaitu ventricular septal defect (VSD), overriding aorta, stenosis pulmonal, serta hipertrofi ventrikel kanan. Kelainan yang menentukan derajat beratnya penyakit, adalah stenosis pulmonal, yang bervariasi dari sangat ringan hingga berupa atresia pulmonal ${ }^{2}$.

Ventricular Septal Defect (VSD) adalah lubang di antara ventrikel yang akan menyebabkan darah yang kurang akan oksigen bercampur dengan darah yang kaya akan oksigen. Stenosisi pulmonalis merupakan penyumbatan yang terjadi dari ventrikel ke paru-paru yang disebabkan oleh blockade aliran darah dari ventrikel kanan ke paruparu karena pembuluh yang menyempit kearah arteri pulmonaris, biasanya bersamaan dengan katup pulmonari yang abnormal. Disamping itu, overriding aorta di antara ventrikel akan membiarkan darah yang kurang oksigen mengalir ke aorta yang juga disebabkan oleh penebalan dan pembesaran otot jantung pada ventrikel kanan (hipertropi ventrikel kanan). Bersama dengan defek septum ventrikel dan stenosis pulmonalis, overriding aorta menyebabkan tingkat oksigen 
dalam darah menjadi rendah. Hal ini menyebabkan terjadinya penampakkan kebiruan atau sianosisi karena darah yang kurang oksigen dialirkan ke seluruh tubuh ${ }^{3}$.

Sirkulasi darah penderita ToF berbeda dibanding pada anak normal. Kelainan yang memegang peranan penting adalah stenosis pulmonal dan VSD. Tekanan antara ventrikel kiri dan kanan pada pasien ToF adalah sama akibat adanya VSD. Hal ini menyebabkan darah bebas mengalir bolak-balik melalui celah ini. Aliran darah ke paru akan menurun akibat adanya hambatan pada jalan aliran darah dari ventrikel kanan; hambatan yang tinggi di sini akan menyebabkan makin banyak darah bergerak dari ventrikel kanan ke kiri. Hal ini berarti makin banyak darah miskin oksigen yang akan ikut masuk ke dalam aorta sehingga akan menurunkan saturasi oksigen darah yang beredar ke seluruh tubuh, dapat menyebabkan sianosis. Jika terjadi hambatan parah, tubuh akan bergantung pada duktus arteriosus dan cabang-cabang arteri pulmonalis untuk mendapatkan suplai darah yang mengandung oksigen. Onset gejala, tingkat keparahan sianosis yang terjadi sangat bergantung pada tingkat keparahan hambatan yang terjadi pada jalan keluar aliran darah di ventrikel kanan ${ }^{4}$.

\section{Pembahasan}

\section{Definisi}

ToF adalah malformasi jantung kongenital sianotik dengan komponen stenosis pulmonal, defek septum ventrikel, dekstroposisi aorta yang menyebabkan pangkal aorta melewati septum ventrikel/ over-riding aorta, serta hipertrofi ventrikel kanan $^{5}$

\section{Etiologi}

Penyakit jantung kongenital yang salah satunya ToF, disebabkan oleh gangguan perkembangan sistem kardiovaskular pada masa embrio. Terdapat peranan faktor endogen, eksogen, dan multifaktorial (gabungan dari kedua faktor tersebut). Para ahli cenderung berpendapat bahwa penyebab endogen dan eksogen tersebut jarang secara terpisah menyebabkan penyakit jantung kongenital ${ }^{5}$.

\section{Patogenesis}

Embriologi jantung bermulai dari adanya tuba. Terdapat dua bagian tuba, yaitu trunkus arteriosus dan bulbus kordis yang berkembang menuju satu sama bawah, menuju bulbus kordis. Perputaran ini akan memisahkan aorta dengan arteri pulmonal. Deviasi ke arah anterior dari perputaran ini menyebabkan ToF. Deviasi anteroseptal pada pembentukan lubang septum ventrikular dapat disertai dengan pembentukan jaringan fibrosa pada septum yang gagal mengalami proses muskularisasi. Deviasi ini dapat ditemukan pada absennya obsrtuksi subpulmonal, seperti pada defek septum ventrikel Eisenmenger. Oleh karena itu, pada pasien dengan ToF, perlu dipastikan adanya morfologi abnormal dari trabekula septoparietal yang melingkari traktur aliran subpulmonal. Kombinasi adanya deviasi septum dan trabekulasi septoparietal yang hipertrofi menghasilkan karakteristik adanya obstruksi aliran ventrikel kanan. Deviasi jaringan muskular pada lubang septum juga menyebabkan adanya defek septum ventrikel dengan gangguan alignment dan menyebabkan munculnya overriding dari aorta. Hipertrofi miokardium ventrikel kanan merupakan konsekuensi hemodinamik akibat adanya lesi yang disebabkan oleh deviasi lubang septum ${ }^{4}$.

\section{Patofisiologi}

Komponen yang paling penting, yang menentukan derajat beratnya penyakit, adalah 
stenosis pulmonal, yang bervariasi dari sangat ringan sampai sangat berat, bahkan dapat berupa atresia pulmonal. Stenosis pulmonal ini bersifat progresif, semakin lama semakin berat. Tekanan yang meningkat akibat stenosis pulmonal menyebabkan darah yang terdeoksigenasi (yang berasal dari vena) keluar dari ventrikel kanan menuju ventrikel kiri melalui defek septum ventrikel dan ke sirkulasi sistemik melalui aorta, menyebabkan hipoksemia sistemik dan sianosis. Bila stenosis pulmonal semakin berat, maka semakin banyak darah dari ventrikel kanan menuju ke aorta. Pada stenosis pulmonal yang ringan, darah dari ventrikel kanan menuju ke paru, dan hanya pada aktivitas fisik akan terjadi pirau dari kanan ke kiri. Semakin bertambahnya usia, maka infundibulum akan semakin hipertrofik, sehingga pasien akan semakin sianotik. Obstruksi pada jalan keluar ventrikel kanan ini menyebabkan kurangnya aliran darah ke paru yang menyebabkan hipoksia, maka kompensasi untuk hipoksia adalah terjadinya polisitemia dan dibentuknya sirkulasi kolateral (jangka panjang) ${ }^{6}$.

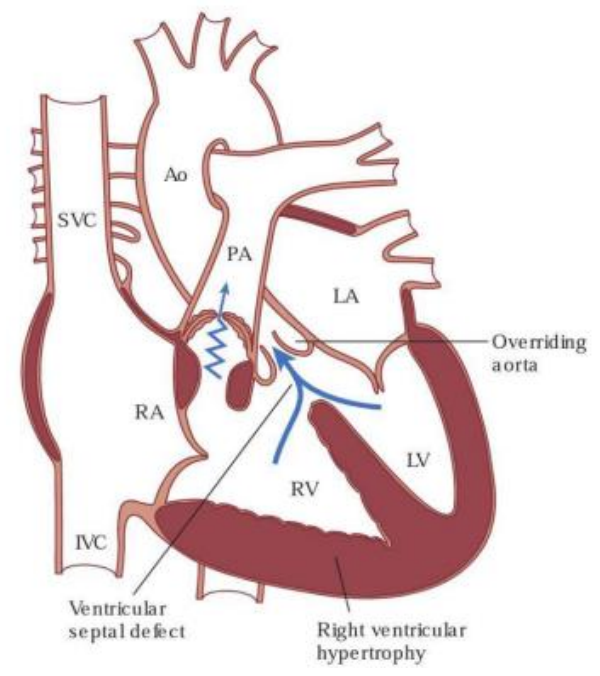

Gambar 1. Aliran Darah Jantung pada Tetralogi Fallot ${ }^{6}$

Terdapatnya defek septum ventrikel yang besar disertai stenosis pulmonal, maka tekanan sistolik puncak (peak systolic pressure) ventrikel kanan menjadi sama dengan tekanan sistolik puncak ventrikel kiri. Karena tekanan ventrikel kiri berada dalam pengawasan baroreseptor, maka tekanan sistolik ventrikel kanan tidak akan melampaui tekanan sistemik. Hal inilah yang menerangkan mengapa pada tetralogi Fallot tidak atau jarang terjadi gagal jantung, karena tidak ada beban volume sehingga ukuran jantung umumnya normal ${ }^{7}$.

\section{Manifestasi Klinis ${ }^{1}$}

1. Wajah bengkak dan edema pitting pada tangan

2. Maternal history of infections, drug intake, and disease

3. Warna kulit bayi terlihat kebiru-biruan terutama pada palatum, lidah dan mukosa bibir bagian dalam

4. Murmur simptomatik atau asimptomatik

5. Keluhan kesulitan makan pada anak

6. Perubahan warna pada bibir dan kuku terutama saat anak menangis

7. Perkembangan fisik yang buruk

8. Denyut nadi yang tidak normal

9. Riwayat infeksi, asupan obat, dan penyakit pada saat hamil

\section{Manifestasi rongga mulut ${ }^{1}$}

1. Perubahan warna kebiru-biruan pada mukosa mulut

2. Delayed eruption pada gigi permanen

3. Cleft palate, midline abnormalities, and growth abnormalities

4. Meningkatnya insidensi karies gigi karena tingginya kandungan gula pada obat sirup

5. Meningkatnya insidensi penyakit periodontal

6. Xerostomia akibat efek samping obat jantung 
7. Kebersihan rongga mulut yang buruk dan hipertropi gingiva

8. Geographic tounge

9. Maloklusi dan susunan gigi tidak rapi

10. Enamel hipoplasia dan dental neglect
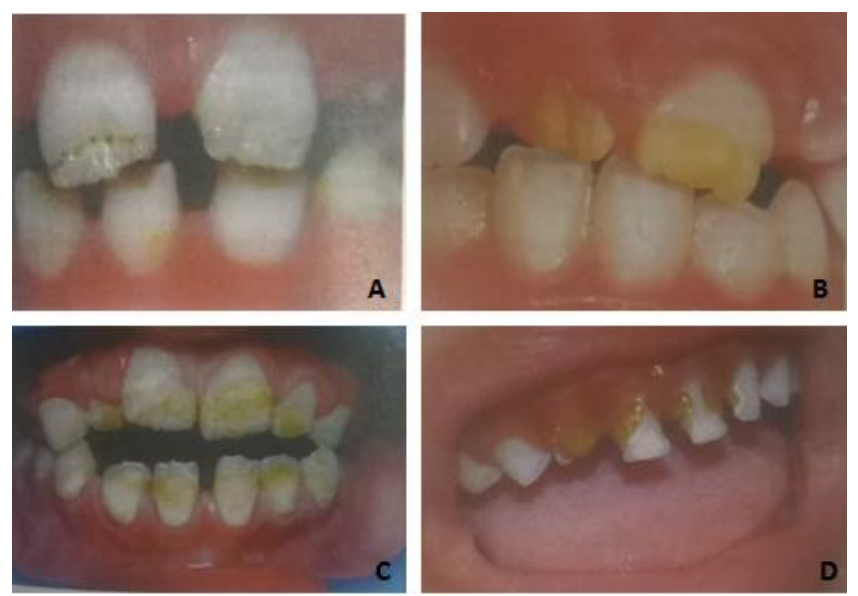

Gambar 2. (A) pitting hypoplastic defects on enamel, (B) enamel defect in an eruption dentition, (C) hypoplastic defects of enamel, (D) high caries risk $^{1}$

\section{Perawatan gigi dan mulut ${ }^{1}$}

Tujuan utama pemberian antibiotic profilaksis adalah untuk melindungi pasien dari perkembangan bakteri endokarditis

Untuk tujuan perawatan, pasien dibagi dalam empat kategori

1. Unrepaired heart defect

2. Repaired heart defect

3. Uncomplicated repair pada penyakit jantung congenital lebih dari 6 bulan

4. Pemasangan protesa jantung

Kategori 1,2,3 memerlukan profilaksis, dan hany kategori 4 yang tidak memerlukan profilaksis

\section{Diskusi}

Menifestasi klinis ToF mencerminkan derajat hipoksia. Pada waktu baru lahir biasanya bayi belum sianotik; bayi tampak biru setelah tumbuh. Manifestasi klinis ToF mula - mula dapat mirip dengan defek septum ventrikel dengan pirau dari kiri ke kanan dengan stenosis pulmonal ringan, sehingga anak masih kemerahan. Apabila derajat stenosis bertambah, akan timbul sianosis ${ }^{8}$.

Salah satu manifestasi yang penting pada ToF adalah terjadinya serangan sianotik (cyanotic spells, hypoxic spells, paroxysmal hyperpnea) yang ditandai oleh timbulnya sesak napas mendadak, napas cepat dan dalam, sianosis bertambah, lemas, bahkan dapat pula disertai kejang atau sinkop. Serangan tersebut dapat berlangsung selama beberapa menit hingga jam, sehingga hipoksemia dapat berujung pada kerusakan sel - sel otak. Serangan yang hebat dapat berakhir dengan koma, bahkan kematian. Serangan sianotik bisa timbul mendadak, walaupun menangis, pergerakan usus, dan menyusui/makan dapat memicunya. Frekuensi serangan sianotik bertambah pada musim panas dan ada infeksi. Kateterisasi jantung dan supraventricular tachycardia juga dikatakan dapat memicu terjadinya serangan. Terdapat berbagai hal yang dapat memicu terjadinya serangan tersebut, sehingga sangat sulit menentukan faktor - faktor yang pasti. Mekanisme terjadinya serangan sianotik belum diketahui secara pasti, namun beberapa hipotesis telah dikemukakan, antara lain peningkatan kontraktilitas infundibular, vasodilatasi perifer, hiperventilasi, dan stimulasi mekanoreseptor ventrikel kanan ${ }^{9}$.

Anak dengan ToF biasanya belajar untuk meringankan gejala yang dialaminya dengan posisi jongkok (squatting position) setelah dapat berjalan; setelah berjalan beberapa lama, anak akan berjongkok untuk beberapa waktu sebelum ia berjalan kembali. Hal ini terjadi sebagai mekanisme kompensasi. Hal tersebut mungkin telah dipelajari oleh anak sejak bayi dengan mengadopsi knee-chest posture. Posisi jongkok dapat menyebabkan peningkatan resistensi 
sistemik vaskular dengan melekukkan arteri femoralis, sehingga menurunkan pirau kanan ke kiri dan meningkatkan aliran darah ke paru ${ }^{6}$.

Pada bayi bentuk dada normal, namun pada anak yang lebih besar dapat tampak menonjol akibat pelebaran ventrikel kanan. Jari tabuh (clubbing fingers) dapat mulai terlihat setelah pasien berusia 6 bulan. Anak dapat menjadi iritatif dalam keadaan kadar oksigen berkurang, atau memerlukan asupan oksigen yang lebih banyak, anak dapat menjadi mudah lelah, mengantuk, atau bahkan tidak merespons ketika dipanggil, menyusu yang terputus-putus. Pada anak dengan ToF, biasanya dijumpai keterlambatan pertumbuhan, tinggi dan berat badan dan ukuran tubuh kurus yang tidak sesuai dengan usia anak².

Seperti penyakit jantung kongenital lainnya, ToF seringkali berkaitan dengan komplikasi yang fatal, seperti endokarditis bakterialis yang berhubungan dengan infeksi gigi. Insidensi endokarditis bakterial pada ToF sebesar $15 \%$. Dalam hubungannya dengan kedokteran gigi, endokaritis bakterial berhubungan erat dengan infeksi gigi10. Kondisi gigi yang buruk seringkali ditemui pada anak-anak dengan ToF dalam hubungannya dengan gangguan pada perkembangan enamel (gangguan mineralisasi enamel). Anak-anak dengan ToF beresiko tinggi terjadinya karies, khususnya pada gigi sulung. Hal ini mungkin juga disebabkan oleh medikasi tertentu untuk penyakit jantung yang mana mengandung konsentrasi gula yang tinggi. Sering juga terjadi hipertrofi gingiva dan geographic tongue ${ }^{11}$.

Tindakan preventif, termasuk konseling diet, pemakaian fluoride, pit and fissure sealant, serta dental health education. Anak-anak dengan ToF harus mendapatkan pemeriksaan yang teliti yaitu inspeksi jaringan lunak ekstraoral, inspeksi intraoral (jaringan keras gigi dan jaringan periodontal), dan pemeriksaan penunjang berupa foto radiography terbaru. Perawatan gigi seperti ekstraksi, scalling, bedah mulut, perawatan endodontik mungkin menyebabkan bakteriemia. Prosedur gigi yang memungkinkan terjadinya trauma pada jaringan lunak maupun jaringan keras mungkin menyebabkan perdarahan yang dapat menyebabkan bakteriemia. Dengan demikian diperlukan adanya usaha untuk mencegah terjadinya edokarditis bakterial dengan penggunaan profilaksis antibiotik. Streptokokus oral seperti S.sanguin dan S.mitis yang merupakan organisme yang paling banyak menyebabkan endokarditis bakterialis ${ }^{11}$.

\section{DAFTAR PUSTAKA}

1. Gupta P. V. Pediatric Dentistry for Special Child. New Delhi: Jaypee Brothers Medical Publishers. 2016. Page : 109-123

2. Schmitz ML, Ullah S. Anesthesia for right-sided obstructive lessions. Dalam: Andropoulos DB, Stayer SA, Russell IA, Mossad EB, penyunting. Anesthesia for congenital heart disease. Edisi ke-2. New York: Blackwell Publishing; 2005. hlm. 332-8.

3. Lake CL, Booker PD. Tetralogy of Fallot. Dalam: Lake CL, Booker PD, penyunting. Pediatric cardiac anesthesia. Edisi ke4. Philadelphia: Lippincott Williams \& Wilkins; 2005. hlm. 345-57.

4. Kleigman RM, et al. Nelson textbook of pediatrics. 19th ed. 2011. Philadelphia:Elsevier-Saunders.

5. Aftab S, Usman A, Sultan T. Frequency of Cerebrovascular Accidents and Brain Abcess in Children with Tetralogy of Fallot. Pakistan Journal of Neurological Sciences (PJNS). 2015 June 2;10(2);23-6.

6. Lilly, Leonard S. Pathopyshiology of Heart Disease: A Collaborative Project of Medical Students and Faculty. 6th Ed. Philadelphia: Lippincott Williams \& Wilkins. 2015. p:393-6.

7. Bailliard F, Anderson R. Tetralogy of Fallot. Orphanet Journal of Rare Diseases. 2009 Jan 13;4(2):1-10.

8. Duro RP, Moura C, Leite-Moreira A. Anatomophysiologic basis of tetralogy of Fallot and its clinical implications. Revista portuguesa de cardiologia: orgao oficial da Sociedade Portuguesa de Cardiologia. Portuguese journal 
of cardiology : an official journal of the Portuguese Society of Cardiology. 2010 Apr;29(4):591-630.

9. Bhatnagar S, Naware S, Kuber R, Thind SS. Pediatric stroke: Neurological sequelae in uncorrected tetralogy of fallot. Annals of medical and health sciences research. 2013;3(1a):27-30.
10. Welbury Richard. Paediatric Dentistry3'd ed. New York: Oxford University Press, 2005: 89-1 07

11. Koch G, Poulsen S. Pediatric dentistry, a clinical aPProach. Copenhagen : Munks g aar d, $2001: 428$. 